\title{
Characterization of Purine Hydroxylase I from Aspergillus nidulans
}

\author{
By RAJ K. MEHRA ${ }^{1}$ AND MICHAEL P. COUGHLAN ${ }^{2 *}$ \\ ${ }^{1}$ The Agricultural Institute, Moorepark Research Centre, Fermoy, Co. Cork, Ireland \\ ${ }^{2}$ Department of Biochemistry, University College, Galway, Ireland
}

(Received 19 August 1988; revised 15 October 1988; accepted 25 October 1988)

Purine hydroxylase I from Aspergillus nidulans was purified 850 -fold. The purified preparations exhibited the spectral and catalytic properties, including broad specificity for oxidizing and reducing substrates, typical of molybdenum/flavin/iron-sulphur-containing hydroxylases (oxotransferases).

\section{INTRODUCTION}

Molybdenum-containing hydroxylases are widely distributed among prokaryotic and eukaryotic species (Krenitsky et al., 1974; Wurzinger \& Hartenstein, 1974; Coughlan, 1980a). These enzymes, which may more properly be termed oxotransferases (Berg \& Holm, 1985a,b), were until quite recently thought to include only aldehyde oxidase, nitrate reductase, xanthine oxidase and xanthine dehydrogenase. However, in the last twenty years the number of enzymes identified as belonging to this group has increased to about fifteen (e.g. Massey, 1973; Coughlan, 1980 b, 1983; Friedrich et al., 1986; Hinojosa-Leon et al., 1986; Turner et al., 1987; Bell et al., 1988). They are unique in that they all possess a molybdopterin cofactor (Johnson, 1980; Johnson \& Rajagopalan, 1982). Among the enzymes in this group are the purine hydroxylases I and II from Aspergillus nidulans. These have been submitted to thorough genetic analysis (Lewis et al., 1978; Scazzocchio, 1980; Scazzocchio \& Sealy-Lewis, 1978; Scazzocchio et al., 1973). However, while some properties of purine hydroxylase I have been examined using crude extracts (Lewis et al., 1978), only purine hydroxylase II has been purified and subjected to extensive biochemical characterization and electron paramagnetic resonance spectroscopy (Coughlan et al., 1984; Mehra \& Coughlan, 1984). We report here some of the biochemical properties of purified purine hydroxylase I.

\section{METHODS}

Organism. The biotin-requiring Aspergillus nidulans strain biA-1 used in these studies was kindly provided by Professor Claudio Scazzocchio, Université Paris-Sud, Orsay, France. The organism was grown as described previously using 2-thioxanthine $\left(0.5 \mathrm{mg} \mathrm{l}^{-1}\right)$ to induce synthesis of purine hydroxylase I (Scazzocchio et al., 1973).

Electrophoresis. Protein purity and $\boldsymbol{M}_{\mathrm{r}}$ values were estimated by polyacrylamide gradient gel electrophoresis using the procedures recommended by Pharmacia Fine Chemicals (Publication no. 11-B-037-11, August 1978). The gel gradient was 5-27\% and the buffer was 70 mM-Tris, 80 mm-boric acid, 2.5 mm-disodium EDTA, pH 8.3. Standard proteins were those supplied by Pharmacia as the high-molecular-weight calibration kit. Gels were fixed in $10 \%(\mathrm{w} / \mathrm{v})$ trichloroacetic acid and then stained for protein in $0.2 \%(\mathrm{w} / \mathrm{v})$ gel electrophoresis blue 83 in water/methanol/acetic acid $(6: 3: 1$, by vol.) and destained in water/methanol/acetic acid $(6: 3: 1$, by vol. $)$ until the background was clear. Replicate gels were stained for activity using a mixture of hypoxanthine $(450 \mu \mathrm{M})$ and either nitroblue tetrazolium $\left(1.27 \mathrm{mg} \mathrm{ml}^{-1}\right)$ or $p$-iodonitrotetrazolium $(3 \mathrm{mM})$ in $0.1 \mathrm{M}$-sodium pyrophosphate buffer, pH 7.8, containing $0.2 \mathrm{~mm}$-EDTA. The gels were scanned densitometrically at $550 \mathrm{~nm}$ (protein or activity stains) by using a Pye Unicam SP1800 spectrophotometer specially adapted for that purpose.

Isoelectric focusing. This was done using Pharmalytes covering the $\mathrm{pH}$ range 3-10, the procedure and the isofocusing standard proteins recommended by Pharmacia Fine Chemicals (Publication no. 01-900-2-1464-02). Gels were stained for protein or activity as above and pI values were determined by comparison with those of standards. 
Enzyme assays. Reactions were carried out at $25^{\circ} \mathrm{C}$ in 100 mM-sodium pyrophosphate buffer, $\mathrm{pH} 7 \cdot 8$, containing $200 \mu \mathrm{M}$-EDTA in a final volume of $1.0 \mathrm{ml}$. The oxidation of hypoxanthine $(450 \mu \mathrm{M})$ by the following acceptors, their concentrations, and the wavelengths at which reactions were monitored, were as follows: oxygen (i.e. air-saturated buffer, $2.3 \mathrm{mM} ; 278 \mathrm{~nm}) ; 2$,6-dichlorophenolindophenol $(50 \mu \mathrm{M} ; 600 \mathrm{~nm})$; trinitrobenzene sulphonate $(0.5 \mathrm{mM} ; 278 \mathrm{~nm})$; phenazine methosulphate $(0.1 \mathrm{mM} ; 278 \mathrm{~nm})$; methylene blue $(20 \mu \mathrm{M} ; 278 \mathrm{~nm})$; $\mathrm{NAD}^{+}(2.26 \mathrm{~mm} ; 340 \mathrm{~nm})$; ferricyanide $(2 \mathrm{mM} ; 420 \mathrm{~nm})$. The molar absorption coefficient differences at the appropriate wavelengths between substrate and product (or oxidized and reduced acceptor) were: hypoxanthine, $83331 \mathrm{~mol}^{-1} \mathrm{~cm}^{-1}$; ferricyanide, $10401 \mathrm{~mol}^{-1} \mathrm{~cm}^{-1}$ (since reaction was monitored at $420 \mathrm{~nm}$ allowance was made for the fact that for every $1 \mathrm{~mol}$ of hypoxanthine oxidized $2 \mathrm{~mol}$ of ferricyanide were reduced); 2,6-dichlorophenol indophenol, $21000 \mathrm{l} \mathrm{mol}^{-1} \mathrm{~cm}^{-1}$; and NAD, $62201 \mathrm{~mol}^{-1} \mathrm{~cm}^{-1}$. For routine purposes 1 unit of activity is defined as being equivalent to $1 \mu \mathrm{mol}$ NADH produced $\min ^{-1}$. The oxidation of NADH $(450 \mu \mathrm{M})$ by ferricyanide was followed at the appropriate wavelength.

Protein determination. Protein concentration in crude extracts was measured by the method of Hartree (1972) using bovine serum albumin as standard. Enzyme concentration in purified preparations was measured using the previously determined $\varepsilon_{450}$ value for purine hydroxylase II of $72 \mathrm{~mm}^{-1} \mathrm{~cm}^{-1}$ (Mehra \& Coughlan, 1984).

Enzyme purification. All procedures, unless stated otherwise, were carried out at $4^{\circ} \mathrm{C}$ using $100 \mathrm{~mm}$-sodium pyrophosphate buffer, $\mathrm{pH} 7.8$, containing $200 \mu \mathrm{M}$-EDTA.

Preparation of crude extract. Frozen cells were thawed in 4 vols buffer and homogenized for 3 min in a 5 litre Waring blender with an equal volume of glass beads $(0.25-0.31 \mathrm{~mm})$, the temperature being maintained below $10^{\circ} \mathrm{C}$ during breakage. The homogenate was centrifuged at $2000 \mathrm{~g}$ for $30 \mathrm{~min}$ using a Mistral $6 \mathrm{~L}$ centrifuge. The supernatant, hereinafter called the crude extract, was collected. The enzyme activity in such extracts was very unstable but was stabilized somewhat by ammonium sulphate fractionation as described below.

Ammonium sulphate fractionation. Ammonium sulphate (final concentration $30 \%$ saturation) was added slowly to the crude extract with stirring, the $\mathrm{pH}$ being maintained at 7.8 using $\mathrm{NaOH}$. Stirring was continued for 30 min after the last addition of salt. Following centrifugation the supernatant was collected and ammonium sulphate was added to it to give $55 \%$ saturation. Following equilibration and centrifugation the precipitate was collected, resuspended in 4 vols $(\mathrm{w} / \mathrm{v}) 50 \mathrm{~mm}-\mathrm{Tris} / \mathrm{HCl}$ buffer, $\mathrm{pH} 7.8$, containing $0.2 \mathrm{~mm}$-EDTA and clarified by centrifugation at $27000 \mathrm{~g}$ for $30 \mathrm{~min}$. The $\mathrm{pH}$ of the supernatant, which was collected, was adjusted to 7.8 when necessary.

Acetone fractionation. Acetone, at $-20^{\circ} \mathrm{C}$, was added dropwise with stirring to the above supernatant to a final concentration of $50 \%(\mathrm{v} / \mathrm{v})$, the temperature being maintained between -5 and $0{ }^{\circ} \mathrm{C}$ using a salt-ice bath. The mixture was stirred for $10 \mathrm{~min}$ after the last addition of acetone and then centrifuged for $1 \mathrm{~min}$ at $20000 \mathrm{~g}$ at $-10^{\circ} \mathrm{C}$. The precipitate was resuspended in 4 vols $50 \mathrm{mM}$-Tris/ $\mathrm{HCl}$ buffer, $\mathrm{pH} 7 \cdot 8$, containing $0 \cdot 2 \mathrm{mM}$-EDTA, and centrifuged at $27000 \mathrm{~g}$ for $30 \mathrm{~min}$. The enzyme solution was concentrated by precipitation with ammonium sulphate $(50 \%, \mathrm{w} / \mathrm{v})$ and redissolving in a small volume of $50 \mathrm{mM}-\mathrm{Tris} / \mathrm{HCl}$ buffer, $\mathrm{pH} 7.8$, containing $0.2 \mathrm{mM}-$ EDTA.

Gel filtration. Samples $(3.2 \mathrm{ml})$ of enzyme from the previous step were applied to a Sephadex G-200 column $(2.5 \times 59 \mathrm{~cm}$; bed volume $290 \mathrm{ml})$ pre-equilibrated with $50 \mathrm{~mm}$-Tris $/ \mathrm{HCl}$ buffer, $\mathrm{pH} 7.8$, containing $0.2 \mathrm{mM}$ EDTA. Flow rate was set at $10 \mathrm{ml} \mathrm{h}^{-1}$ and $2 \mathrm{ml}$ fractions were collected. Protein was eluted by irrigation with the same buffer. Enzyme activity eluted as a single symmetrical peak. Fractions of high specific acitivity were pooled. Activity was relatively stable at this stage. In subsequent runs Sephadex G-200 was replaced by Sephacryl-300 because of ease of packing and better flow rates. In this case $10 \mathrm{ml}$ samples of enzyme solution from the ammonium sulphate step were applied to a 1 litre column of Sephacryl-300 pre-equilibrated with $50 \mathrm{~mm}-\mathrm{Tris} / \mathrm{HCl}$ buffer, $\mathrm{pH} 7 \cdot 8$, containing $0 \cdot 2$ mM-EDTA.

Ion-exchange chromatography. The pooled enzyme from the previous step was applied to a Whatman DE 52 cellulose column $(0.7 \times 13.0 \mathrm{~cm}$; bed volume $5 \mathrm{ml})$ equilibrated with $50 \mathrm{mM}$-Tris/HCl buffer, pH 7.8 , containing $0.2 \mathrm{mM}$-EDTA. The column was then irrigated with this buffer containing $0 \cdot 1 \mathrm{M}-\mathrm{NaCl}$ until protein no longer eluted. A linear gradient $(150 \mathrm{ml})$ of 0.1 to $0.4 \mathrm{M}-\mathrm{NaCl}$, in the above buffer, was then applied at a flow rate of $20 \mathrm{ml} \mathrm{h}^{-1}$. Fractions $(1.65 \mathrm{ml})$ were collected. Enzyme activity was eluted at $0.13-0.16 \mathrm{M}-\mathrm{NaCl}$. Fractions of highest specific activity were pooled.

\section{RESULTS AND DISCUSSION}

The purification scheme outlined above and summarized in Table 1 resulted in an 850-fold purification of purine hydroxylase I with a yield of about $9 \%$.

\section{Properties of purine hydroxylase I}

Absorption spectrum. The absorption spectra of hydroxylases containing molybdenum, flavin and iron-sulphur prosthetic groups are characterized by peaks at $280 \mathrm{~nm}$ and $450 \mathrm{~nm}$ (the latter 


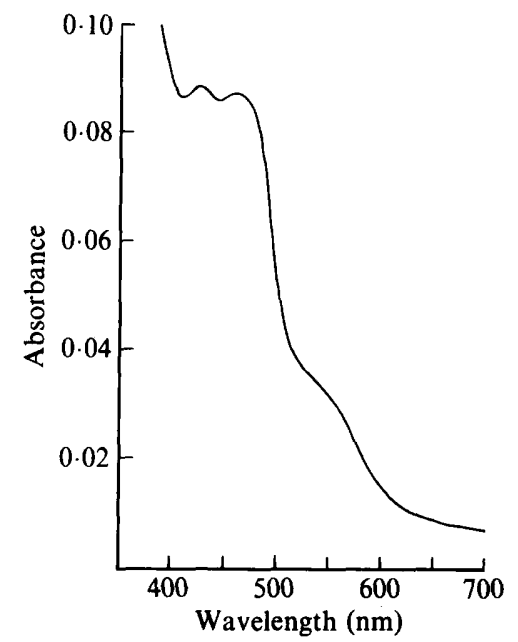

Fig. 1. Visible absorption spectrum of purine hydroxylase $I$.

Table 1. Purification of purine hydroxylase I

\begin{tabular}{|c|c|c|c|c|c|c|}
\hline Fraction & $\begin{array}{l}\text { Volume } \\
\text { (ml) }\end{array}$ & $\begin{array}{l}\text { Total protein } \\
\text { (mg) }\end{array}$ & $\begin{array}{l}\text { Total activity } \\
\text { (units) }\end{array}$ & $\begin{array}{c}\text { Specific activity } \\
{\text { [units (mg protein) })^{-1} \text { ] }}^{\text {(mg }}\end{array}$ & $\begin{array}{l}\text { Purification } \\
\text { (-fold) }\end{array}$ & $\begin{array}{c}\text { Yield } \\
(\%)\end{array}$ \\
\hline Crude extract & 7010 & 35729 & $50 \cdot 1$ & 0.0014 & 1 & 100 \\
\hline $\begin{array}{l}\text { Ammonium sulphate } \\
(30-55 \% \text { cut })\end{array}$ & 940 & $5541 \cdot 3$ & $39 \cdot 1$ & 0.0071 & 5 & 78 \\
\hline Acetone $(0-50 \%$ cut $)$ & 240 & $236 \cdot 9$ & $35 \cdot 5$ & $0 \cdot 15$ & 107 & $70 \cdot 9$ \\
\hline Sephadex G-200 & $21 \cdot 5$ & $17 \cdot 1$ & $8 \cdot 3$ & 0.486 & 347 & $16 \cdot 6$ \\
\hline Cellulose DE 52 & 40 & 3.9 & $4 \cdot 6$ & $1 \cdot 19$ & 850 & $9 \cdot 2$ \\
\hline
\end{tabular}

being due mainly to the flavin chromophores) and a shoulder at $550 \mathrm{~nm}$ reflecting the absorption by the iron-sulphur centres (Coughlan, 1980a). Purified preparations of such enzymes have $A_{280} / A_{450}$ ratios of 5 and $A_{450} / A_{550}$ ratios of about 3 (Rajagopalan \& Handler, 1964; Coughlan, $1980 \mathrm{a}$ ). The visible absorption spectrum of purified purine hydroxylase I showed the expected absorption at $450 \mathrm{~nm}$ and the characteristic shoulder at $550 \mathrm{~nm}$ (Fig. 1). The $A_{450} / A_{550}$ ratio of the preparation shown was $2 \cdot 7$. Thus, purine hydroxylase $I$ is typical of that group of molybdenum/flavin/iron-sulphur enzymes that contain $2(2 \mathrm{Fe}-2 \mathrm{~S})$ centres per mol flavin (Rajagopalan \& Handler, 1964). The visible spectra revealed that the enzyme preparations obtained using the procedure outlined above were not contaminated by coloured protein (Coughlan, $1980 a$ ). However, variation of the $A_{280} / A_{450}$ ratios of several purine hydroxylase I preparations between 9 and 11 indicated that such preparations were contaminated with colourless protein (see below).

Electrophoretic properties. Polyacrylamide gradient gel electrophoresis of a typical preparation demonstrated the presence of two protein bands, only one of which stained for activity. The $M_{\mathrm{r}}$ value of the contaminating protein was between 386000 and 400000 while that of the purine hydroxylase I band was calculated to be between 260000 and 280000 . This is slightly lower than the usual value of about 300000 for such enzymes (Coughlan, 1980a) and the value of 304000 reported for purine hydroxylase I in crude extracts (Lewis et al., 1978) but is in agreement with the value of $260000-280000$ for partially purified preparations of this enzyme (H.M. SealyLewis \& C. Scazzocchio, personal communication). These workers found that proteolysis occurring, without loss of activity, during isolation was responsible for the decrease in the $M_{\mathrm{r}}$ value of the native enzyme. In view of this finding and since hydrolysis of molybdoenzymes by endogenous proteases during isolation is a common observation (see e.g. Waud et al., 1975), we 


\section{Table 2. Electron acceptor utilization by purine hydroxylase I}

In all cases hypoxanthine $(450 \mu \mathrm{M})$ was the reducing substrate. Catalytic centre activity is expressed as mol substrate oxidized (mol enzyme subunit) $)^{-1} \mathrm{~min}^{-1}$. Enzyme subunit concentration was calculated from the $A_{450}$ of the enzyme solution and a subunit $\varepsilon_{450}$ value of $36 \mathrm{mM}^{-1} \mathrm{~cm}^{-1}$ (Coughlan, 1980a; Mehra \& Coughlan, 1984).

Electron acceptor
Ferricyanide
Phenazine methosulphate
Dichlorophenolindophenol
Trinitrobenzene sulphonate
Methylene blue
$\mathrm{NAD}^{+}$
$\mathrm{O}_{2}$

$\begin{array}{cc}\begin{array}{c}\text { Apparent } \\ (\mu \mathrm{M})\end{array} & \begin{array}{c}\text { Catalytic centre } \\ \text { activity }\end{array} \\ 2000.0 & 662 \\ 7.0 & 935 \\ 45.5 & 546 \\ 540.0 & 443 \\ 190.0 & 354 \\ 331.0 & 342 \\ \text { ND } & 0.8\end{array}$

ND, Not determined.

may presume that the purine hydroxylase I preparations isolated here have also been subject to proteolysis. The most dramatic consequence of such hydrolysis of rat liver xanthine dehydrogenase is that its ability to utilize $\mathrm{NAD}^{+}$as an electron acceptor is greatly decreased while the utilization of oxygen is greatly increased; i.e. the enzyme is converted from a dehydrogenase to an oxidase (Waud \& Rajagopalan, 1976a,b). Such is not the case with purine hydroxylase $I$, the enzyme being a true dehydrogenase throughout the purification process (see below).

Densitometric scanning of electrophoretic gels in the present study suggested that purine hydroxylase I accounted for at least $60 \%$ of the total protein of the purified preparations. On isoelectric focusing, only one protein band, which also stained for activity, was obtained, indicating that both purine hydroxylase I and the contaminating protein had a pI value of 5.0. Procedures used in attempts to obtain further purification of purine hydroxylase $I$ included calcium phosphate gel chromatography, chromatofocusing, preparative polyacrylamide gel electrophoresis and affinity chromatography on Sepharose 4B-folate (Nishino et al., 1982) or Blue-Sepharose gels. Such procedures have proven successful with the corresponding enzymes from other sources but did not prove to be so in the case of purine hydroxylase $I$.

Specificity for electron acceptors. Purine hydroxylase I, as isolated, is a true dehydrogenase in that it utilizes $\mathrm{NAD}^{+}$rather than oxygen in the hydroxylation of substrates. Thus, with hypoxanthine $(450 \mu \mathrm{M})$ as reducing substrate, the catalytic centre activity [i.e. mol substrate oxidized (mol enzyme subunit) ${ }^{-1} \mathrm{~min}^{-1}$ ] with oxygen as oxidizing substrate was only 0.8 while that with $\mathrm{NAD}^{+}$was 342 . The apparent $K_{\mathrm{m}}$ value for the latter, the probable acceptor in vivo, was $331 \mu \mathrm{M}$. As is the case with all of the molybdenum hydroxylases isolated to date, purine hydroxylase I could catalyse the transfer of electrons to a variety of artificial acceptors. The apparent $K_{\mathrm{m}}$ values and catalytic centre activities with such acceptors are given in Table 2.

Specificity for reducing substrates. Purine hydroxylase I was able to catalyse the oxidation of $\mathrm{NADH}$ and the hydroxylation of a wide variety of purines, pyrimidines, pteridines and aldehydes, albeit at different rates (Table 3). In that it has broad reducing substrate specificity, purine hydroxylase $I$ is similar to all other xanthine oxidases, xanthine dehydrogenases and aldehyde oxidases examined to date (Krenitsky et al., 1972; Coughlan, 1980a). The ability to catalyse the hydroxylation of xanthine and the inability to act on nicotinic acid distinguish it from purine hydroxylase II from the same organism (Lewis et al., 1978; Mehra \& Coughlan, 1984). The relative rates of action of the purified purine hydroxylase I upon hypoxanthine, xanthine and nicotinic acid are in agreement with the results obtained using crude extracts of $A$. nidulans biA-1 (Lewis et al., 1978). We concur with the conclusion of these authors that, in vivo, purine hydroxylase I is primarily engaged in purine metabolism and purine hydroxylase II in nicotinate metabolism.

A number of points with regard to substrate specificity are deserving of further comment. The fact that adenine, 6-mercaptopurine, 6-methoxypurine and 6-thioxanthine were not acted upon 
Table 3. Reducing substrate specificity of purine hydroxylase I

Except where stated otherwise, the final reducing substrate concentration was $450 \mu \mathrm{M}$. NAD ${ }^{+}$ $(2.26 \mathrm{mM})$ was the acceptor in all but one case. Activities are expressed as a percentage of that given with hypoxanthine as substrate.

\begin{tabular}{lrc}
\multicolumn{1}{c}{ Substrate } & $\begin{array}{c}\text { Relative } \\
\text { rate }\end{array}$ & $\begin{array}{c}\text { Apparent } K_{\mathrm{m}} \\
(\mu \mathrm{M})\end{array}$ \\
Hypoxanthine (6-hydroxypurine) & $100 \cdot 0$ & $16 \cdot 4$ \\
Adenine (6-aminopurine) & $0 \cdot 7$ & \\
6-Mercaptopurine & $1 \cdot 8$ & \\
6-Methoxypurine & $1 \cdot 8$ & \\
Xanthine (2,6-dihydroxypurine) & $61 \cdot 6$ & $34 \cdot 2$ \\
2-Thioxanthine (2-thio-6-hydroxypurine) & $28 \cdot 6$ & $15 \cdot 6$ \\
6-Thioxanthine (2-hydroxy-6-thiopurine) & $2 \cdot 1$ & \\
8-Chloroxanthine (2,6-dihydroxy-8-chloropurine) & 0 & \\
Purine & $21 \cdot 8$ & $10 \cdot 7$ \\
2-Hydroxypurine & $42 \cdot 9$ & $16 \cdot 8$ \\
Nicotinic acid & $0 \cdot 6$ & \\
$N^{1}$-Methylnicotinic acid & $0 \cdot 2$ & \\
$N^{1}-$ Methylnicotinamide & 0 & \\
4-Hydroxypyrazolo[3,4-d]pyrimidine (allopurinol) & $7 \cdot 6$ & \\
4-Aminopyrazolo[3,4-d]pyrimidine & $0 \cdot 8$ & \\
4-Mercaptopyrazolo[3,4-d]pyrimidine & $0 \cdot 4$ & \\
2-Amino-4-hydroxypteridine (pterin) & $19 \cdot 8$ & \\
2-Amino-4,6-dihydroxypteridine & $8 \cdot 1$ & \\
Folic acid & $0 \cdot 4$ & \\
Benzaldehyde (4.3 mM) & $24 \cdot 1$ & $1370 \cdot 0$ \\
Formaldehyde (30 mM) & $6 \cdot 2$ & \\
Acetaldehyde (30 mM) & $0 \cdot 5$ & \\
NADH (2 mM-ferricyanide as acceptor) & $115 \cdot 3$ & $63 \cdot 5$ \\
& &
\end{tabular}

suggests that substitutions at position 6, other than $-\mathrm{H}$ (purine) or $-\mathrm{OH}$ (hypoxanthine), prevented productive binding to the active site. Substitution of the $-\mathrm{H}$ at position 8 (as in xanthine) or by $-\mathrm{Cl}$ (8-chloroxanthine) completely abolished activity. By contrast, substitution at position 2 had relatively little effect. Thus, 2-thioxanthine was converted to 2 -thiouric acid at half the rate of conversion of xanthine to uric acid while 2-hydroxypurine was acted upon at twice the rate of utilization of purine. The finding that 2-hydroxypurine did not support growth of the organism whereas xanthine (2,6-dihydroxypurine) did indicates that 2-hydroxypurine is hydroxylated at position 8 rather than at position 6 (Scazzocchio \& Sealy-Lewis, 1978). The inability to utilize $N^{1}$-methylnicotinamide at $\mathrm{pH} 7.8$ is not surprising. Purine hydroxylase II (Mehra \& Coughlan, 1984), milk xanthine oxidase (Greenlee \& Handler, 1964) and turkey liver xanthine dehydrogenase (Cleere \& Coughlan, 1975) cannot act on this substrate at physiological pH but can do so at higher pH values. Greenlee \& Handler (1964) interpreted such findings as indicating the presence at the active centre of xanthine oxidase of a residue, possibly lysine, with a pK of $10 \cdot 7$. In the protonated form this would repel the positively charged substrate. In the case of milk xanthine oxidase the $K_{\mathrm{m}}$ values for aldehyde substrates are of the order of millimolar or greater. The situation with respect to purine hydroxylase $I$ is clearly the same. Finally, we note that purine hydroxylase I, like the avian xanthine dehydrogenases (Coughlan, 1980a), readily catalyses the oxidation of NADH.

This work was supported by a grant (to M.P.C.) from the National Board for Science and Technology, Ireland.

\section{REFERENCES}

Bell, J. M., Colby, J. \& Williams, E. (1988). CO oxidoreductase from Streptomyces strain G26 is a molybdenum hydroxylase. Biochemical Journal 250, 605-612.
BERG, J. M. \& HolM, R. H. (1985a). Model for the active site of oxo-transfer molybdoenzymes: synthesis, structure and properties. Journal of the American Chemical Society 107, 917-925. 
BerG, J. M. \& Holm, R. H. (1985b). Model for the active site of oxo-transfer molybdoenzymes: reactivity, kinetics and catalysis. Journal of the American Chemical Society 107, 925-932.

Cleere, W. F. \& Coughlan, M. P. (1975). Avian xanthine dehydrogenase. I. Isolation and characterization of the turkey liver enzyme. Comparative Biochemistry and Physiology B50, 311-322.

Coughlan, M. P. (1980a). Aldehyde oxidase, xanthine oxidase and xanthine dehydrogenase: hydroxylases containing molybdenum, iron-sulphur and flavin. In Molybdenum and Molybdenum-containing Enzymes, pp. 119-185. Edited by M. P. Coughlan. Oxford: Pergamon Press.

Coughlan, M. P. (editor) (1980b). Molybdenum and Molybdenum-containing Enzymes. Oxford: Pergamon Press.

Coughlan, M. P. (1983). The role of molybdenum in human biology. Journal of Inherited Metabolic Diseases 6, Suppl. 1, 70-77.

Coughlan, M. P., Mehra, R. K., Barber, M. J. \& SIEGEL, L. M. (1984). Optical and electron paramagnetic resonance spectrophotometric studies on purine hydroxylase II from Aspergillus nidulans. Archives of Biochemistry and Biophysics 229, 311-316.

Friedrich, C. C., MEYer, O. \& ChandRA, T. S. (1986). Molybdenum-dependent sulphur oxidation in facultatively lithoautotrophic thiobacteria. FEMS Microbiology Letters 37, 105-108.

Greenlee, L. \& Handler, P. (1964). Xanthine oxidase. VI The influence of $\mathrm{pH}$ on substrate specificity. Journal of Biological Chemistry 239, 10901095.

HARTREe, E. F. (1972). Determination of protein. A modification of the Lowry method that gives a linear photometric response. Analytical Biochemistry 48, 422-427

Hinojosa-Leon, M., Dubourdieu, M., SanchezCrispin, J. A. \& ChIPPAUX, M. (1986). Tetrathionate reductase of Salmonella typhimurium: a molybdenum-containing enzyme. Biochemical and Biophysical Research Communications 136, 577-581.

Jornson, J. L. (1980). The molybdenum cofactor common to nitrate reductase, xanthine dehydrogenase and sulphite oxidase. In Molybdenum and Molybdenum-containing Enzymes, pp. 345-383. Edited by M. P. Coughlan. Oxford: Pergamon Press.

Johnson, J. L. \& Rajagopalan, K. V. (1982). Structure and metabolic relationship between the molybdenum cofactor and urothione. Proceedings of the National Academy of Sciences of the United States of America 79, 6856-6860.

Krenitsky, T. A., Neil, S. M., Elion, G. B. \& Hitchings, G. H. (1972). A comparison of the specificities of xanthine oxidase and aldehyde oxidase. Archives of Biochemistry and Biophysics 150, 585-599.

Krenitsky, T. A., Tuttle, J. V., Cattau, E. L. \& WANG, P. (1974). A comparison of the distribution and electron acceptor specificities of xanthine oxidase and aldehyde oxidase. Comparative Biochemistry and Physiology 49B, 687-703.
Lewis, N. J., Hurt, P., Sealy-Lewis, H. M. \& Scazzocchio, C. (1978). The genetic control of the molybdoflavoproteins in Aspergillus nidulans. IV. A comparison between purine hydroxylase I and II. European Journal of Biochemistry 91, 311-316.

MASSEY, V. (1973). Iron-sulphur flavoprotein hydroxylases. In Iron-Sulphur Proteins, vol. 1, pp. 301-360. Edited by W. Lovenberg. New York: Academic Press.

Mehra, R. K. \& Coughlan, M. P. (1984). Purification and properties of purine hydroxylase II from Aspergillus nidulans. Archives of Biochemistry and Biophysics 229, 585-595.

Nishino, T., Nishino, T. \& Tsushima, K. (1982). On the nature of the cyanolysable sulphur in xanthine oxidase. In Flavins and Flavoproteins, pp. 792-795. Edited by V. Massey \& C. H. Williams. Amsterdam: Elsevier.

Rajagopalan, K. V. \& Handler, P. (1964). The absorption spectra of iron flavoproteins. Journal of Biological Chemistry 239, 1509-1514.

Scazzocchio, C. (1980). The genetics of the molybdenum-containing enzymes. In Molybdenum and Molybdenum-Containing Enzymes, pp. 487-515. Edited by M. P. Coughlan. Oxford: Pergamon Press.

Scazzocchio, C. \& Sealy-Lewis, H. M. (1978). A mutation in the xanthine dehydrogenase (purine hydroxylase I) of Aspergillus nidulans resulting in altered specificity. Implications for the geometry of the active site. European Journal of Biochemistry 91, 99-109.

Scazzocchio, C., Holl, F. B. \& Foguelman, A. I. (1973). The genetic control of molybdoflavoproteins in Aspergillus nidulans. Allopurinol-resistant mutants constitutive for xanthine dehydrogenase. European Journal of Biochemistry 36, 428-445.

Turner, N., Barata, B., Bray, R. C., Deistung, J., Le Gall, J. \& Moura, J. J. G. (1987). The molybdenum iron-sulphur protein from Desulfovibrio gigas as a form of aldehyde oxidase. Biochemical Journal 243, 755-761.

Waud, W. R. \& Rajagopalan, K. V. (1976a). Purification and properties of the $\mathrm{NAD}^{+}$-dependent (type $\mathrm{D}$ ) and $\mathrm{O}_{2}$-dependent (type $\mathrm{O}$ ) forms of rat liver xanthine dehydrogenase. Archives of Biochemistry and Biophysics 172, 365-379.

Waud, W. R. \& Rajagopalan, K. V. (1976b). The mechanism of conversion of rat liver xanthine dehydrogenase from an $\mathrm{NAD}^{+}$-dependent form (type D) to an $\mathrm{O}_{2}$-dependent form (type $\mathrm{O}$ ). Archives of Biochemistry and Biophysics 172, 354-364.

Waud, W. R., BRady, F. O., Wiley, R. D. \& Rajagopalan, K. V. (1975). A new purification procedure for bovine milk xanthine oxidase: effect of proteolysis on the subunit structure. Archives of Biochemistry and Biophysics 169, 695-701.

WURZINGER, K. H. \& HARTENSTEIN, R. (1974). Phylogeny and correlations of aldehyde oxidase, xanthine oxidase, xanthine dehydrogenase and peroxidase in animal tissues. Comparative Biochemistry and Physiology 49B, 171-185. 